\title{
Perlindungan Hukum Terhadap Partisipasi Masyarakat (Anti SLAPP) Dalam Penegakan Hukum Lingkungan Hidup di Indonesia
}

\author{
Nani Indrawati \\ nan_070662@yahoo.co.id \\ Mahkamah Agung Republik Indonesia
}

\begin{abstract}
Keywords: Abstract
Anti-SLAPP; Anti SLAPP is a new terminology that was first recognized in the United States in 1996. Public Basically, Anti-SLAPP is a legal policy that provides legal protection for people who fight Participation; for the public interest's purposes acknowledged in constitutional and statutory provisions. Environmental Law In Indonesia, the provisions which are similar to Anti-SLAPP in the environmental area Enforcement. (anti-eco SLAPP) is included in Article 66 of the Law on Environmental Protection and Management (LEPM) which intends to protect environmental defenders from criminal charges and lawsuits for exposing environmental rights violation. Law enforcers, especially judges, are still having difficulty in detecting cases that are indicated as SLAPP and stop the case to continue in the early stage. Article 66 of the LEPM are a symbol of legal protection, as well as a manifestation of the accommodative attitude of the LEPM towards the importance of environmental public participation including protecting individuals and groups who fight for the environmental rights against criminal charges and civil litigation. The lack of provisions on the procedures and mechanisms of the Anti-SLAPP makes it difficult to implement Article 66 of the LEPM. Consequently, law enforcers particularly court judges apply and interpret Article 66 of LEPM is not in line with the original intention of Anti SLAPP's provision.
\end{abstract}

Kata Kunci:
Anti-SLAPP;
Partisipasi
Masyarakat;
Penegakan
Hukum
Lingkungan
Hidup.

Abstrak

Anti-SLAPP merupakan terminologi baru yang dikenal pertama kali di Amerika Serikat pada tahun 1996. Pada intinya Anti-SLAPP adalah ketentuan yang memberikan perlindungan hukum terhadap masyarakat yang memperjuangkan kepentingan publik yang diakui dalam konstitusi dan perundang-undangan. Di Indonesia, ketentuan serupa dengan Anti-SLAPP dibidang lingkungan hidup (anti-eco SLAPP) termuat dalam Pasal 66 Undang-Undang tentang Perlindungan dan Pengelolaan Lingkungan Hidup (UU PPLH) yang dimaksudkan untuk melindungi para pembela lingkungan hidup dari tuntutan pidana dan gugatan perdata karena mengungkap pelanggaran hak atas lingkungan hidup. Para penegak hukum khususnya hakim masih mengalami kesulitan mendeteksi kasus yang terindikasi SLAPP dan menghentikan kasus pada tahap awal. Ketentuan Pasal 66 UU PPLH merupakan simbol perlindungan hukum, sekaligus sebagai wujud dari sikap akomodatif UU PPLH terhadap pentingnya peran serta masyarakat, termasuk melindungi individu dan kelompok masyarakat yang memperjuangkan hak atas lingkungan hidup dari tuntutan pidana dan gugatan perdata. Ketiadaan ketentuan tentang prosedur dan mekanisme Anti-SLAPP menyulitkan implementasi Pasal 66 UU PPLH. Akibatnya, para penegak hukum khususnya hakim dalam menerapkan dan menafsirkan Pasal 66 UU PPLH berbeda dengan tujuan awal ketentuan Anti SLAPP. 


\section{Pendahuluan}

Partisipasi masyarakat dalam rangka melindungi lingkungan hidup yang baik dan sehat sering mendapat perlawanan dari pelaku usaha yang aktifitas usahanya diduga/telah menimbulkan pencemaran atau perusakan lingkungan hidup. Perbuatan pelaku usaha dengan melakukan pelaporan kepada pihak polisi ataupun menggugat masyarakat terdampak atau para pemerhati/pejuang hak atas lingkungan hidup atau aktivis lingkungan hidup yang melakukan partisipasi masyarakat dalam bentuk menyampaikan informasi, pengaduan, keberatan baik melalui media ataupun demonstrasi dimaksudkan oleh Penggugat ataupun Pelapor adalah untuk membungkam dan menghentikan partisipasi mereka untuk kepentingan publik, sehingga menimbulkan rasa takut sehingga masyarakat/ aktivis lingkungan hidup tidak lagi berani bersuara untuk menyampaikan pengaduan ataupun mengkritisi kegiatan usaha pelaku usaha yang diduga/ telah menimbulkan pencemaran atau perusakan lingkungan hidup. Gugatan atau pelaporan pidana tersebut dikenal dengan istilah SLAPP (Strategic Law Suit Agains Public Participation). ${ }^{1}$ SLAPP adalah gugatan ataupun gugatan rekonvensi (secara perdata) dan/atau pelaporan kepada polisi (secara pidana) yang diajukan oleh pelaku usaha terhadap masyarakat (korban) atau pejuang hak atas lingkungan hidup yang mengkritisi atau mengajukan keberatan sebagai bentuk partisipasi masyarakat terhadap aktifitas usaha pelaku usaha yang diduga menimbulkan pencemaran/perusakan lingkungan hidup. Gugatan tersebut dimaksudkan untuk membungkam atau menghentikan peran serta masyarakat. Hal ini dapat juga terjadi pada saat pelapor yang melaporkan adanya pencemaran/perusakan lingkungan hidup, dilaporkan balik dengan dalil pencemaran nama baik. Dalam praktek, seringkali hakim lebih fokus pada gugatan Penggugat dengan dalil perbuatan melanggar hukum atau surat dakwaan Jaksa Penuntut Umum dan melupakan pokok permasalahan, yaitu pencemaran/perusakan lingkungan

${ }^{1}$ Rapiuddin Hamarung, 'Perlindungan Terhadap Peran Serta Masyarakat (Anti-Strategic Lawsuit Againts Public Paticipation (SLAPP Suit)' in Henri Subagiyo (ed), Anotasi Undang-Undang Nomor 32 Tahun 2009 tentang Perlindungan dan Pengelolaan Lingkungan Hidup (Edisi Pertama) (1st edn, ICEL 2014).[70]. 
hidup. ${ }^{2}$ Salah satu kasus awal yang terindikasi SLAPP di Indonesia terjadi pada tahun 2004 sebelum adanya UU PPLH, yaitu kasus Dr. Rignolda Djamaludin, seorang ahli lingkungan hidup. Ia menyampaikan pendapatnya di harian Kompas tanggal 20 Juli 2004 dan harian Sinar Harapan tanggal 21 Juli 2004 mengenai operasi pertambangan yang dilakukan oleh PT. Newmont Minahasa Raya (PT. NMR) yang diduga telah melakukan pencemaran di Teluk Buyat, Sulawesi Utara, pencemaran tersebut diduga menyebabkan penyakit minamata yang diidap oleh masyarakat sekitar Teluk Buyat. Artikel di 2 (dua) surat kabar tersebut kemudian menimbulkan respon dari PT. NMR yang mengambil langkah hukum dengan menggugat Rignolda Djamaludin dengan dalil gugatan Perbuatan Melanggar Hukum (Pasal 1365 Burgerlijk Wetboek Voor Indonesie/BW). ${ }^{3}$ Gugatan Perbuatan Melanggar Hukum tersebut dikabulkan oleh Pengadilan Negeri Manado dan dikuatkan oleh Pengadilan Tinggi Manado, namun putusan tersebut dibatalkan oleh Mahkamah Agung di tingkat kasasi dengan pertimbangan hukum bahwa alas hak (dasar gugatan) Termohon Kasasi semula Penggugat untuk menggugat Pemohon Kasasi semula Tergugat adalah pemberitaan dari 2 (dua) surat kabar Kompas dan Sinar Harapan, dalam pemberitaan pada kedua surat kabar tersebut ditegaskan bahwa sumber berita (subjek hukumnya) adalah Direktur Yayasan Kelola Sulawesi Utara dan anggota stafnya (Kompas) dan Surat Kabar Sinar Harapan tanpa melibatkan stafnya. Penyebar luasan berita/sumber berita adalah Pers. Berdasarkan pada pemberitaan tersebut, maka seharusnya yang digugat adalah Direktur Yayasan Kelola Sulawesi Utara (Badan Hukum), sehingga Mahkamah Agung memutus bahwa gugatan Penggugat (Termohon Kasasi) terdapat kesalahan subjek yang digugat sehingga dalam amar putusan menyatakan gugatan Penggugat tidak dapat diterima (perkara Nomor 278/Pdt.G/2004/PN. Mdo jo. Nomor 28/PDT/2006/PT. Mdojo. Nomor 1720K/PDT/2006), dan beberapa kasus lain yang terus bermunculan.

\footnotetext{
${ }^{2}$ Kementerian Lingkungan Hidup, 'Perlindungan Terhadap Peran Serta Masyarakat (AntiStrategic Lawsuit Againts Public Paticipation (SLAPP Suit)', Anotasi Undang-Undang Nomor 32 Tahun 2009 tentang Perlindungan dan Pengelolaan Lingkungan Hidup (Edisi Pertama) (ICEL 2014).[76].

${ }^{3}$ Abdul Khalik and Fitri Wulandari, 'Buyat Bay Test Show High Mercury' <http:/ /www. minesandcommunities.org/article.php? $\mathrm{a}=1391>$.
} 
Beberapa tahun sejak kasus Rignolda, di Indonesia muncul kasus-kasus lain yang diindikasikan sebagai SLAPP. Hal tersebut menjadi pertimbangan pembentuk undang-undang yang kemudian berinisiatif untuk memasukkan pasal yang mengatur tentang perlindungan hukum terhadap partisipasi masyarakat dalam undang-undang lingkungan hidup. Hal itu dimaksudkan untuk melindungi peran serta/partisipasi masyarakat dalam menjaga lingkungan hidup yang baik dan sehat, yang selanjutnya dimanifestasikan dalam Pasal 66 UU PPLH. Namun, meskipun telah ada aturan bahwa pemerhati/ pejuang hak atas lingkungan hidup yang memperjuangkan hak atas lingkungan hidup yang baik dan sehat tidak dapat digugat ataupun dilaporkan polisi sebagaimana bunyi Pasal 66 UU PPLH, tapi fenomena menggugat para korban ataupun para pejuang hak atas lingkungan hidup terus terjadi, antara lain gugatan Willy Suhartanto (Direktur PT. Panggon Sarkarya Sukses Mandiri) yang membangun The Rayja Batu Resort mengajukan gugatan perbuatan melanggar hukum (Pasal 1365 BW) terhadap H. Rudy, koordinator Forum Masyarakat Peduli Mata Air (FMPMA) yang memperjuangkan agar pembangunan resort tersebut dihentikan karena dapat memberikan dampak negatif terhadap sumber mata air Gemulo di kota Malang. Perkara tersebut diputus oleh Pengadilan Negeri Malang pada tanggal 21 Juli 2014, dalam amar putusannya Majelis Hakim menolak gugatan Willy Suhartanto dan mengabulkan gugatan Rekonvensi Tergugat (H. Rudy) serta menghukum Tergugat Rekonvensi untuk membayar uang sejumlah Rp.2.000.000,- (dua juta rupiah). Majelis Hakim pemeriksa perkara tersebut mempertimbangkan bahwa Izin Mendirikan Bangunan (IMB) The Rayja Batu Resort melanggar hukum karena jarak antara sumber mata air dengan bangunan hotel hanya 150 meter, sedangkan jarak minimum seharusnya 200 meter, dalam amar putusan Majelis Hakim memerintahkan agar pembangunan The Rayja Batu Resort dihentikan. ${ }^{4}$ Putusan Pengadilan Negeri Malang tersebut dikuatkan oleh Pengadilan Tinggi Surabaya, namun di tingkat kasasi putusan tersebut dibatalkan dengan pertimbangan hukum bahwa putusan

\footnotetext{
${ }^{4}$ Iksan Fauzi, 'Tiga Tahun Konflik Terus, The Rayja Ditawarkan 35 Miliar' Tribunnews $<$ surabaya.tribunnews.com>.
} 
Judex Facti Pengadilan Tinggi Surabaya yang menguatkan putusan Pengadilan Negeri Malang telah salah menerapkan hukum, dengan pertimbangan bahwa Judex Facti telah salah dalam mempertimbangkan eksepsi Tergugat/Termohon Kasasi tentang gugatan kabur, dimana dalam posita gugatan ternyata berisi mengenai tindakan Tergugat/Termohon Kasasi yang menurut Penggugat/Pemohon Kasasi adalah perbuatan melanggar hukum karena melakukan pengancaman kepada warga sekitar, melakukan pengiriman surat keberatan masyarakat kepada instansiinstansi terkait, melakukan provokasi kepada warga sekitar untuk melakukan demo, serta melakukan pengrusakan pagar milik Penggugat/Pemohon Kasasi, tetapi pada bagian petitum berisi mengenai permohonan pengesahan surat-surat izin pembangunan villa/hotel dan rekomendasi dari instansi terkait yang telah diterima oleh Penggugat/Pemohon Kasasi, sehingga tidak jelas hubungan antara petitum dengan posita gugatan, dan dalam gugatan rekonvensi yang diajukan oleh Termohon Kasasi/Tergugat terbukti kedudukan Termohon Kasasi/Tergugat Konvensi/Penggugat Rekonvensi adalah tidak jelas yaitu apakah dia mengajukan gugatan rekonvensi dalam kedudukannya sebagai perorangan atau mewakili kelompok. Majelis Hakim Tingkat Kasasi kemudian memutus dan mengadili sendiri dengan amar putusan dalam eksepsi mengabulkan eksepsi Tergugat, dalam pokok perkara menyatakan gugatan Penggugat tidak dapat diterima (niet ontvankelijk verklaard), dan dalam rekonvensi menyatakan gugatan Penggugat Rekonvensi tidak dapat diterima (niet ontvankelijk verklaard), (perkara Nomor 177/Pdt.G/2013/PN.Mlg jo. Nomor 701/PDT/2014/PT.SBY jo. Nomor 2263K/ PDT/2015). Demikian pula di Pengadilan Negeri Cibinong tahun 2018, seorang ahli (Dr. Basuki Wasis) digugat perdata (dengan dalil perbuatan melanggar hukum) yang diajukan oleh Terpidana kasus korupsi (mantan Gubernur Sulawesi Tenggara) dengan posita gugatan bahwa ahli telah menyampaikan pendapat tentang perhitungan kerugian ekologi dan ekonomi akibat perbuatan Terdakwa dalam suatu persidangan perkara tipikor, yang merugikan Penggugat. Perkara lainnya yang terindikasi SLAPP adalah perkara pidana dengan klasifikasi perkara pelanggaran jabatan. Perkara ini didasarkan pada penolakan Robandi, dkk 
terhadap bantuan pangan dari PT Bangka Asindo Agri (BAA) kepada masyarakat yang berada di wilayah administrasi Rukun Tetangga (RT) Robandi, dkk. PT BAA kemudian melaporkan Robandi, dkk karena dianggap tidak memiliki lagi kewenangan sebagai ketua RT untuk membuat surat penolakan bantuan pangan. Sebelumnya Robandi, dkk juga menjadi pihak dalam perkara perdata lingkungan hidup melawan PT BAA.

\section{Metode Penelitian}

Penelitian ini merupakan penelitian hukum normatif sehingga metode yang digunakan adalah metode penelitian hukum yaitu proses untuk menemukan aturan-aturan hukum, prinsip-prinsip hukum, maupun doktrin-doktrin hukum dalam menjawab permasalahan hukum yang dikemukakan dalam penelitian ini, sehingga dapat diperoleh suatu konklusi pada permasalahan penelitian ini terkait dengan perlindungan hukum terhadap partisipasi masyarakat. Penelitian ini menggunakan pendekatan peraturan perundang-undangan yakni dengan menelaah dan mengkaji aturan hukum yang terkait dengan Anti-Strategic Lawsuit Against Public Participation. Selain pendekatan peraturan perundang-undangan di dalam penelitian ini juga digunakan pendekatan kasus yakni menelaah kasuskasus yang terkait dengan Strategic Lawsuit Against Public Participation.

\section{Hak atas Lingkungan Hidup yang Baik dan Sehat}

Pasal 28H ayat (1) UUDN 1945 mengamanatkan bahwa Setiap orang berhak hidup sejahtera lahir batin, bertempat tinggal dan mendapatkan lingkungan hidup yang baik dan sehat serta berhak memperoleh pelayanan kesehatan. Dalam konsideran huruf a UU PPLH diuraikan bahwa lingkungan hidup yang baik dan sehat merupakan hak asasi setiap warga Negara Indonesia sebagaimana diamanatkan dalam Pasal 28H UUDN 1945. Amanat dari Pasal 28H UUDN 1945 tersebut diatur secara khusus dalam ketentuan Pasal 65 ayat (1) UU PPLH, bahwa setiap orang berhak atas lingkungan hidup yang baik dan sehat sebagai bagian dari hak asasi manusia. Pada ayat (4) pasal tersebut mengatur bahwa setiap orang berhak 
untuk berperan dalam perlindungan dan pengelolaan lingkungan hidup sesuai dengan peraturan perundang-undangan, dengan demikian UU PPLH memberikan pengakuan yang lebih kuat terhadap hak untuk berperan serta dari masyarakat dibandingkan dengan undang-undang lingkungan hidup sebelumnya.

Hak untuk mendapatkan lingkungan hidup yang baik dan sehat telah diakui pada Deklarasi Stockholm dan Deklarasi Rio.

Deklarasi Stockholm

Principle 1

"Man has the fundamental right to freedom, equality and adequate conditions of life, in an environment of a quality that permits a life of dignity and well-being, and he bears a solemn responsibility to protect and improve the environment for present and future generations...". ${ }^{5}$

Terjemahan bebas:

Pasal 1

"Manusia memiliki hak fundamental untuk kebebasan, kesetaraan dan kondisi kehidupan yang memadai, dalam lingkungan hidup yang berkualitas yang memungkinkan kehidupan yang bermartabat dan sejahtera, dan ia memikul tanggung jawab serius untuk melindungi dan meningkatkan lingkungan untuk generasi sekarang dan akan datang...".

Deklarasi Rio

Principle 1

"Human beings are at the centre of concerns for sustainable development. They are entitled to a healthy and productive life in harmony with nature". 6

Terjemahan bebas:

Pasal 1

"Manusia adalah pusat perhatian bagi pembangunan berkelanjutan. Mereka berhak atas kehidupan yang sehat dan produktif selaras dengan alam".

Tahun 1990 UN General Assembly mengeluarkan resolusi Need to ensure a healthy environment for the well-being of individuals yang mengakui bahwa semua individu berhak untuk hidup di lingkungan hidup yang memadai, untuk

\footnotetext{
${ }^{5}$ United Nations Environment Programme, 'Declaration of The United Nations Conference on the Human Environment' <http:/ / www.unep.org> accessed 26 November 2014.

${ }^{6}$ United Nations Environment Programme, 'Rio Declaration on Environment and Development' <http:/ / www.unep.org> accessed 24 September 2014.
} 
kesehatan dan kesejahteraan mereka. ${ }^{7}$

Indonesia telah mengakui hak atas lingkungan hidup sejak Undang-Undang Nomor 4 Tahun 1982 tentang Ketentuan-Ketentuan Pokok Pengelolaan Lingkungan Hidup, yang diperkuat dalam perubahan undang-undang lingkungan hidup selanjutnya. Undang-undang lingkungan hidup di Indonesia telah mengakui pentingnya setiap orang untuk memiliki hak dan mendapatkan lingkungan hidup yang baik dan sehat.

Pengakuan hak atas lingkungan hidup yang baik dan sehat sebagai bagian dari HAM memberikan implikasi yang cukup signifikan bagi hubungan hukum antara masyarakat dengan negara. Hak atas lingkungan hidup sebagai bagian dari HAM melahirkan kewajiban konstitusi bagi negara dalam menghormati (to respect), memenuhi (to fulfill), dan melindungi (to protect). Dalam menjalankan kewajiban konstitusi ini, menurut Heringa sebagaimana dikutip dalam "Naskah Akademik UU PPLH", negara wajib:8

a. Menterjemahkan prinsip perlindungan lingkungan hidup sebagai bagian dari perlindungan hak asasi manusia dalam peraturan perundang-undangan;

b. Berupaya untuk melindungi hak asasi tersebut dan melakukan upaya-upaya yang layak untuk melindungi hak tersebut;

c. Mematuhi hukum yang sudah dibuat oleh negara itu sendiri (dalam hal ini berarti pemerintah wajib mematuhi peraturan perundang-undangan yang berlaku);

d. Memastikan bahwa kepentingan setiap warga negara untuk mendapatkan lingkungan hidup yang baik dan sehat diperhatikan dan diperlakukan seimbang dengan kepentingan publik, termasuk di dalamnya memastikan bahwa setiap warga negara dijamin hak-hak proseduralnya dan mendapat kompensasi apabila haknya dilanggar;

e. Memastikan bahwa pengelolaan lingkungan hidup dilakukan secara transparan dan bahwa setiap warga negara dapat berpartisipasi dalam setiap pengambilan keputusan yang mempengaruhi hajat hidupnya.

Pengakuan terhadap hak akses atas informasi, partisipasi, dan keadilan di bidang lingkungan hidup. Pengakuan ini menunjukkan bahwa UU PPLH menaruh

\footnotetext{
${ }^{7}$ United Nations, 'The Need to Ensure a Healthy Environment for The Well-Being Individuals' <www.un.org> accessed 27 May 2018.

${ }^{8}$ Dewan Perwakilan Rakyat Republik Indonesia, 'Naskah Akademik Rancangan UndangUndang Tentang Pengelolaan Lingkungan Hidup' (2009.[23].
} 
perhatian terhadap akses bagi tercapainya hak atas lingkungan hidup yang baik dan sehat. Akses masyarakat terhadap informasi, partisipasi, dan keadilan dipandang sangat penting dalam mencapai pemenuhan hak atas lingkungan hidup yang baik dan sehat. Negara juga mempunyai kewajiban untuk memberikan perlindungan hukum bagi setiap orang yang memperjuangkan hak atas lingkungan hidup yang baik dan sehat. Ketentuan ini bermaksud memperkuat kedua jaminan hak di atas dengan memastikan bahwa hukum harus melindungi setiap orang yang memperjuangkan hak atas lingkungan hidup yang baik dan sehat.

\section{Anti Eco-SLAPP}

Sebelum memahami konsep Anti Eco-SLAPP, terlebih dahulu harus dapat dipahami pengertian dari SLAPP. Secara sederhana, SLAPP dapat diartikan sebagai tindakan strategis melalui pengadilan untuk menghilangkan partisipasi masyarakat. ${ }^{9}$ Sesuai dengan pengertiannya, tujuan dari SLAPP pada dasarnya untuk membungkam/menghilangkan partisipasi masyarakat. ${ }^{10}$ Namun demikian hingga saat ini, belum ada pengertian yang baku mengenai SLAPP di Indonesia, yaitu tentang siapa yang dapat dilindungi oleh Pasal 66 UU PPLH dan apakah prinsip, kriteria dan karakteristik Anti SLAPP telah diterapkan dengan tepat dalam pertimbangan hukum putusan hakim Indonesia.

Merujuk pengertian di negara lain, yaitu Filipina melalui Rules of Procedures for Environmental Cases, memberikan pengertian SLAPP sebagai berikut: ${ }^{11}$

"A legal action filed to harass, vex, exert undue pressure or stifle any legal recourse that any person, institution or the government has taken or may take in the enforcement of environmental laws, protection of the environment or assertion of environmental rights shall be treated as a SLAPP and shall be governed by these Rules."

${ }^{9}$ Dwight Merriam and Jeffrey Benson, 'Identifying and Beating a Strategic Lawsuit Against Public Participation' (1993) 3 Duke Environmental Law \& Policy Forum.[17].

${ }^{10}$ Josi Khatarina, 'SLAPP Suit in Indonesia: How It Takes Its Form and How To Beat It', Anotasi Undang-Undang Nomor 32 Tahun 2009 tentang Perlindungan dan Pengelolaan Lingkungan Hidup (Edisi Pertama) (ICEL 2014).[2].

Section 1 Rule 6.

${ }^{11}$ Republic of The Philippines Supreme Court, Rules of Procedures for Environmental Cases, 
Terjemahan bebas:

"Sebuah tindakan hukum yang diajukan untuk melecehkan, mengganggu, memberikan tekanan yang tidak semestinya atau menghambat penegakan hukum yang telah dilakukan atau mungkin dilakukan oleh setiap orang, lembaga atau pemerintah dalam penegakan hukum lingkungan hidup, perlindungan terhadap lingkungan hidup atau tuntutan terhadap hak atas lingkungan hidup haruslah diperlakukan sebagai SLAPP dan diatur oleh peraturan ini"

Awal munculnya konsep SLAPP adalah ketika Pring dan Canan, terinspirasi dari kasus yang dihadapi oleh seorang environmental lawyer di Denver (USA), dimana kliennya yang sedang memperjuangkan haknya atas lingkungan hidup yang baik dan sehat digugat oleh pemerintah dan pencemar. ${ }^{12}$ Setelah itu, Pring dan Canan juga menemukan banyak kasus lain yang menyangkut kepentingan publik yang mendapat perlawanan balik dari pemerintah maupun pihak lain yang mendapatkan keuntungan dari kebijakan pemerintah. Padahal hampir seluruh kasus tersebut terjadi ketika masyarakat menggunakan haknya untuk berpartisipasi, menuliskan keberatan atas sebuah rencana atau program melalui surat kabar, menyampaikan keberatan atau mengajukan petisi terhadap sebuah kebijakan. Hak untuk mengajukan petisi sendiri telah dijamin oleh Amandemen Pertama Konstitusi USA. Konsep Anti SLAPP lahir dari keyakinan Pring dan Canan yang mengatakan bahwa kebebasan menyampaikan pendapat serta berpartisipasi dalam kepentingan publik adalah bagian dari tindakan demokrasi yang dilindungi oleh konstitusi USA. ${ }^{13}$

Di Indonesia usulan pengaturan Anti Slapp disuarakan pertama kali dalam Rapat Dengar Pendapat Umum (RDPU) dengan beberapa organisasi lingkungan hidup pada pembahasan Rancangan Undang-Undang tentang Pengelolaan Lingkungan Hidup. Pengaturan tentang Anti SLAPP di dalam UU PPLH dilatar belakangi beberapa alasan, antara lain: ${ }^{14}$

\footnotetext{
${ }^{12}$ George W Pring and Penelope Canan, SLAPPs: Getting Sued for Speaking Out (1st edn, Temple University Press 1996).[9].

${ }^{13}$ Cornell Law School, 'US Constitution, First Amendment' <https://www.law.cornell.edu/ constitution/first_amendment> accessed 27 May 2018.

${ }^{14}$ Dewan Perwakilan Rakyat Republik Indonesia, 'Risalah UU Tentang Pengelolaan Lingkungan Hidup' (2009).[20].
} 
1. Sering terjadinya pembungkaman terhadap masyarakat yang memperjuangkan kepentingan lingkungan hidup oleh pemerintah atau pihak-pihak lain yang berwenang;

2. Sering terjadinya pelaporan balik dengan dalil pencemaran nama baik kepada masyarakat yang melaporkan kasus lingkungan hidup kepada pihak yang berwajib.

Usulan tersebut kemudian disetujui oleh para perumus UU PPLH karena ketentuan ini penting sebagai suatu sarana perlindungan bagi peran serta masyarakat untuk mewujudkan lingkungan hidup yang baik dan sehat. ${ }^{15}$

Perlindungan terhadap partisipasi masyarakat yang menggunakan haknya untuk berpendapat ataupun menyampaikan keberatan atas kegiatan usaha yang diduga/telah menimbulkan pencemaran ataupun kerusakan lingkungan adalah sejalan dengan amandemen kedua UUDN 1945, Pasal 28E menjamin hak setiap orang untuk menyampaikan pendapat, demikian pula Pasal 44 UU HAM menjamin setiap orang untuk mengajukan pendapat, permohonan, pengaduan, dan atau usulan kepada pemerintah yang bersih, efektif dan efisien. Berdasarkan hal-hal tersebut maka pengaturan tentang Anti Slapp dapat diterapkan dalam peraturan perundang-undangan di Indonesia.

Mendesaknya kepedulian perlindungan terhadap HAM menjadi salah satu alasan MPR mengeluarkan TAP MPR No. XVII/MPR/1998 tanggal 13 November 1998 tentang Hak-Hak Asasi Manusia (HAM). Ketetapan MPR ini sebagai dasar yuridis pembentukan Undang-Undang Nomor 39 Tahun 1999 tentang Hak Asasi Manusia, yang kemudian mengarah untuk perlu adanya pengakuan konstitusional HAM atas lingkungan hidup. Ketentuan hak atas lingkungan hidup secara lengkap dapat dibaca pada Pasal 9 ayat (3) UU HAM. Selanjutnya dalam Pasal 9 sampai Pasal 66 UU HAM ditentukan jenis hak-hak asasi manusia yang diakui dan dilindungi oleh Negara. ${ }^{16}$

${ }^{15}$ Dewan Perwakilan Rakyat Republik Indonesia, 'Rapat Panja UU PPLH DPR RI' (2009).[33].

16 Junior B Gregorius, 'Hak Asasi Manusia (HAM) Atas Lingkungan Hidup (Suatu Rekfleksi Sosio-Yuridis Atas Implementasi Penyelesaian Sengketa Lingkungan)’ (2009) 39 Jurnal Hukum \& Pembangunan.[289]. 
Nani Indrawati: Perlindungan Hukum Terhadap...

HAM atas lingkungan hidup telah diatur secara konstitusional melalui Pasal 28H ayat (1) UUD 1945 yang didukung dengan berbagai undang-undang, seperti UU PPLH, UU HAM, PP No. 4 Tahun 2001 tentang Pengendalian Kerusakan dan atau Pencemaran Lingkungan Hidup yang berkaitan dengan Kebakaran Hutan dan atau Lahan, PP No. 54 Tahun 2000 tentang Lembaga Penyedia Jasa Layanan Penyelesaian Sengketa Lingkungan Hidup di Luar Pengadilan, dan UU No. 41 Tahun 1999 tentang Kehutanan, UU No. 4 Tahun 2009 tentang Pertambangan Mineral dan batubara. Penyelesaian sengketa lingkungan diatur dalam Pasal 87 sampai Pasal 92 UU PPLH sebagai lex generalis. Mekanisme penyelesaian sengketa yang diatur dalam berbagai UU dalam bidang lingkungan hidup tersebut pada dasarnya sama kecuali jumlah ancaman denda dan pidananya. Di dalam praktek, sengketa-sengketa lingkungan hidup dapat diselesaikan di luar pengadilan dan atau melalui pengadilan (court system).

Perlindungan negara terhadap warganya sebagaimana diatur dalam Pasal 66 UU PPLH yang disebut sebagai Anti SLAPP telah dikenal dan dipraktekkan di negara-negara yang menganut common law system, antara lain Amerika Serikat, Kanada, Australia dan Filipina dengan istilah Anti-SLAPP yang merupakan singkatan dari Anti Strategic Lawsuit Against Public Participation. Di dalam literature SLAPP Suit didefinisikan sebagai:

action whether civil, criminal or administrative, brought agains any person, institution or any government agency or local government unit or its official and employees, with the intent to harras, vex, exert undue pressure or stifle any legal recourse that such person, institution or government agency has taken or may take in the inforcement of environmental laws, protection of the environment or assertion of environmental rights.

Terjemahan bebas:

tindakan perdata, pidana atau administrasi yang dilakukan untuk melawan seseorang, institusi atau lembaga pemerintah atau unit pemerintah daerah atau pejabat dan pegawainya dengan tujuan untuk mengganggu, menyakiti, melakukan tekanan, atau membuat tidak berdaya secara hukum kepada seseorang atau institusi atau badan pemerintah yang telah atau akan melakukan penegakan hukum lingkungan, perlindungan lingkungan atau 
tuntutan atas hak-hak lingkungan. ${ }^{17}$

Beberapa negara bagian di Amerika Serikat, Australia, dan Kanada serta Filipina mengatur secara khusus ketentuan tentang Anti-SLAPP, dengan maksud untuk melindungi warganya dari serangan balik berupa gugatan perdata kepada pihak yang mengkritisi aktivitas yang diketahui telah menimbulkan dampak pencemaran atau kerusakan lingkungan hidup.

Anti SLAPP merupakan terminologi baru yang dimasukkan ke dalam Pasal 66 UU PPLH, yang bermaksud untuk memberikan imunitas bagi masyarakat ataupun aktivis/pejuang hak atas lingkungan hidup yang memperjuangkan hak atas lingkungan hidup yang baik dan sehat agar terlepas dari tuntutan pidana maupun gugatan perdata. Ketentuan pasal ini memberikan perlindungan atas upaya-upaya kriminalisasi ataupun gugatan perdata yang terjadi dalam kasus lingkungan hidup. ${ }^{18}$ Beberapa tipe pelanggaran hukum yang terjadi dalam kasus SLAPP seperti fitnah, gangguan yang mempengaruhi aktivitas sehari-hari, gangguan yang dilakukan terhadap pribadi (privat), konspirasi, tindakan yang berbahaya, tindakan yang menimbulkan kerugian, dan seterusnya. Fitnah adalah tipe yang paling umum terjadi pada kasus SLAPP. Namun, pelanggaran hukum dengan tipe-tipe lainnya juga dijadikan dasar perlawanan. ${ }^{19}$ Gugatan perdata atau pelaporan secara pidana yang berindikasi SLAPP selalu tidak berdasar hukum, karena tujuan SLAPP semata-mata untuk membungkam dan menghentikan partisipasi masyarakat yang telah dilakukan oleh Tergugat atau Terdakwa untuk memperjuangkan hak atas lingkungan hidup yang baik dan sehat.

Tindakan hukum yang dilakukan oleh pelaku usaha yang diduga/telah menimbulkan pencemaran ataupun perusakan lingkungan hidup akibat aktifitas usahanya, kemudian menggugat terhadap pemerhati/pejuang hak atas lingkungan

${ }^{17}$ Mahkamah Agung Republik Indonesia, “"Rules of Procedure for Environmental Cases, Rule 1" Buku Materi Ajar Pendidikan Dan Pelatihan Sertifikasi Hakim Lingkungan Hidup, Pelatihan Sertifikasi Hakim Lingkungan Hidup' (2014).[164].

${ }^{18}$ Raynaldo Sembiring, 'Kriminalisasi Atas Partisipasi Masyarakat: Menyisir Kemungkinan Terjadinya SLAPP Terhadap Aktivis Lingkungan Hidup Sumatera Selatan' (2014) 1 Jurnal Hukum Lingkungan Indonesia.[211-212].

${ }^{19}$ Khatarina, Op.Cit.[7]. 
hidup atau korban, ataupun melakukan gugatan rekonvensi ketika digugat oleh pemerhati/pejuang lingkungan hidup ataupun korban dengan dalil perbuatan melanggar hukum, maupun melakukan pelaporan secara pidana kepada pihak Polisi dengan tuduhan melanggar Pasal 310 KUHP atau pasal lainnya, adalah suatu proses hukum yang sah, namun dilatarbelakangi suatu tindakan yang bermaksud untuk membungkam atau menghentikan partisipasi masyarakat yang sulit untuk dideteksi para penegak hukum, khususnya hakim baik dalam memeriksa perkara pidana maupun perdata. Dalam memeriksa gugatan perdata hakim berkonsentrasi terhadap dalil yang diajukan oleh Penggugat (perbuatan melanggar hukum/ Pasal 1365 BW), sedangkan dalam perkara pidana hakim berkonsentrasi terhadap pasal yang didakwakan oleh Jaksa Penuntut Umum dalam surat dakwaan yang pada umumnya adalah tindak pidana pencemaraan nama baik (Pasal 310 ayat (1) KUHP), ataupun pasal dari undang-undang lain dan tidak mempertimbangkan tentang permasalahan lingkungan hidup yang melatar belakangi kasus tersebut.

Setelah 4 (empat) tahun UU PPLH diundangkan, Mahkamah Agung RI mengeluarkan pedoman mengenai Anti SLAPP yaitu dalam Surat Keputusan Ketua Mahkamah Agung Nomor 36/KMA/SK/II/2013 tentang Pemberlakuan Pedoman Penanganan Perkara Lingkungan Hidup (selanjutnya disebut SK KMA No.36/2013), pada huruf B angka 4 menguraikan ...."untuk memutuskan sebagaimana Pasal 66 Undang-Undang RI Nomor 32 Tahun 2009 Tentang Perlindungan dan Pengelolaan Lingkungan Hidup bahwa gugatan Penggugat dan/atau pelaporan tindak pidana dari Pemohon adalah SLAPP yang dapat diajukan baik dalam eksepsi, provisi maupun gugatan rekonvensi (dalam perkara perdata) dan/atau pembelaan (dalam perkara pidana) dan harus diputuskan terlebih dahulu dalam putusan sela". SK KMA No.36/2013 yang merupakan pedoman bagi para Hakim dalam menangani perkara lingkungan hidup, khususnya tentang Anti SLAPP tersebut tidak cukup jelas dalam memberikan pedoman bagi para Hakim dalam menangani perkara yang diindikasikan SLAPP, selain itu Pedoman Penanganan Perkara Lingkungan Hidup tersebut berbentuk surat keputusan yang merupakan pedoman dalam menangani perkara lingkungan 
hidup yang berlaku secara internal untuk Mahkamah Agung dan Badan Peradilan di bawahnya, meskipun SK KMA tersebut mengatur hukum acara namun tidak dapat menjadi lex spesialis dari hukum acara perdata yang diatur dalam HIR/ Rbg maupun KUHAP dalam perkara pidana. Pasal 66 UU PPLH dan SK KMA No.36/2013 tentang Pedoman Penanganan Perkara Lingkungan Hidup tersebut tidak memberikan penjelasan tentang pengertian/definisi SLAPP, apa prinsip, kriteria dan karakteristik Anti SLAPP serta siapa yang termasuk pejuang hak atas lingkungan yang dapat dilindungi oleh Pasal 66 UU PPLH dan bagaimana tahapan hukum acara (perdata maupun pidana) dalam proses pemeriksaan SLAPP agar dapat menghentikan gugatan atau dakwaan dengan cepat,efektif dan berbiaya ringan, sehingga dapat dijadikan pedoman untuk penegak hukum, khususnya hakim dalam menyelesaikan perkara yang berindikasikan SLAPP.

Upaya pembungkaman melalui laporan Polisi ataupun melalui gugatan perdata ke pengadilan terhadap para pemerhati/pejuang hak atas lingkungan hidup ataupun korban dapat mengganggu keterlibatan masyarakat dalam melaksanakan partisipasinya. Oleh karena permasalahan SLAPP merupakan suatu permasalahan yang perlu dipandang sebagai suatu masalah yang memerlukan pengaturan dengan undang-undang dan harus mencerminkan rasa keadilan. Namun harus dapat dipahami bahwa fungsi hukum dan undang-undang sematamata bukan hanya untuk dapat memelihara ketertiban dan menjaga stabilitas negara, namun fungsi yang paling pokok dari undang-undang adalah untuk membimbing masyarakat mencapai keutamaan yakni layak untuk menjadi warga negara dari negara yang ideal. ${ }^{20}$ Dalam UU Kekuasaan Kehakiman, para Hakim diwajibkan untuk dapat menggali nilai-nilai hukum dan rasa keadilan dalam masyarakat. Sebagaimana juga diatur dalam Undang-Undang Republik Indonesia Nomor 3 Tahun 2009 tentang Mahkamah Agung (Lembaran Negara Tahun 2009 Nomor 3, Tambahan Lembaran Negara Nomor 4958, yang selanjutnya disebut UU MA), sehingga dalam kondisi tidak ada ketentuan yang mengatur secara jelas

${ }^{20}$ Bahder Johan Nasution, 'Kajian Filosofis Tentang Konsep Keadilan Dari Pemikiran Klasik Sampai Pemikiran Modern' (2014) 3 Yustisia Jurnal Hukum.[120]. 
Nani Indrawati: Perlindungan Hukum Terhadap...

maka Hakim harus dapat menyelesaikan perkara yang ditanganinya dengan melakukan Rechtsvinding/Judicial Activsm.

\section{Kesimpulan}

Ketentuan Pasal 66 UU PPLH merupakan simbol perlindungan hukum, sekaligus wujud sikap akomodatif UU PPLH terhadap berbagai peran serta masyarakat. Pengaturan yang minim mengenai proses Anti-SLAPP menyebabkan kesulitan bagi penegak hukum untuk menggunakan Pasal 66 UU PPLH tersebut. Pasal 66 UU PPLH telah jelas secara normatif, namun secara implikatif masih ditafsirkan sendiri-sendiri oleh para penegak hukum. SLAPP di Indonesia, berbeda dengan SLAPP yang dikenalkan oleh Pring dan Canan, karena di Indonesia tidak hanya dimaknai untuk gugatan strategis saja, namun juga terjadi dalam perkara pidana. Hingga saat ini Indonesia belum memiliki undang-undang yang secara khusus mengatur mengenai Anti-SLAPP, sedangkan negara-negara lain telah memiliki aturan/undang-undang yang mengatur tentang Anti Slapp secara lengkap, sebagaimana halnya Negara Amerika Serikat, Kanada dan Filipina. Kunci untuk menangani SLAPP adalah melalui pendekatan seimbang yang menjamin hak warga negara untuk berperan dalam partisipasi masyarakat dan melindungi hak Penggugat untuk mengajukan gugatan yang sah dan berdasar hukum di pengadilan. Selain itu filosofi Anti-SLAPP harus dijadikan sebagai dasar bagi undang-undang Anti-SLAPP dalam memberikan hak imunitas/perlindungan bagi masyarakat dan aktivis lingkungan yang memperjuangkan hak atas lingkungan hidup yang baik dan sehat untuk terlepas dari tuntutan pidana maupun gugatan perdata. Konsep Anti-SLAPP terlahir karena keyakinan kelompok pejuang hak atas lingkungan hidup dan pejuang HAM bahwa kebebasan menyampaikan pendapat dan berperan serta dalam masalah yang terkait dengan kepentingan masyarakat adalah tindakan menegakkan demokrasi yang harus dilindungi. Ketentuan Pasal 66 UU PPLH menyiratkan adanya hak imunitas bagi masyarakat dan aktivis lingkungan hidup yang memperjuangkan hak atas lingkungan hidup yang baik dan sehat untuk terlepas dari tuntutan pidana maupun gugatan perdata. 
Ketentuan pasal ini memberikan perlindungan terhadap upayaupaya kriminalisasi yang terjadi dalam kasus lingkungan hidup terhadap partisipasi masyarakat yang sedang memperjuangkan hak atas lingkungan hidup yang baik dan sehat. Secara konseptual berdasarkan ketentuan Pasal 65 ayat (1) UU PPLH menyebutkan bahwa setiap orang berhak atas lingkungan hidup yang baik dan sehat sebagai bagian dari hak asasi manusia.

\section{Daftar Bacaan}

\section{Buku}

Dewan Perwakilan Rakyat Republik Indonesia, 'Naskah Akademik Rancangan Undang-Undang Tentang Pengelolaan Lingkungan Hidup' (2009).

- - , 'Rapat Panja UU PPLH DPR RI' (2009).

- - , 'Risalah UU Tentang Pengelolaan Lingkungan Hidup' (2009).

Hamarung R, 'Perlindungan Terhadap Peran Serta Masyarakat (Anti-Strategic Lawsuit Againts Public Paticipation (SLAPP Suit)' in Henri Subagiyo (ed), Anotasi Undang-Undang Nomor 32 Tahun 2009 tentang Perlindungan dan Pengelolaan Lingkungan Hidup (Edisi Pertama) (1st edn, ICEL 2014).

Kementerian Lingkungan Hidup, 'Perlindungan Terhadap Peran Serta Masyarakat (Anti-Strategic Lawsuit Againts Public Paticipation (SLAPP Suit)', Anotasi Undang-Undang Nomor 32 Tahun 2009 tentang Perlindungan dan Pengelolaan Lingkungan Hidup (Edisi Pertama) (ICEL 2014).

Khatarina J, 'SLAPP Suit in Indonesia: How It Takes Its Form and How To Beat It', Anotasi Undang-Undang Nomor 32 Tahun 2009 tentang Perlindungan dan Pengelolaan Lingkungan Hidup (Edisi Pertama) (ICEL 2014).

Mahkamah Agung Republik Indonesia, “'Rules of Procedure for Environmental Cases, Rule 1" Buku Materi Ajar Pendidikan Dan Pelatihan Sertifikasi Hakim Lingkungan Hidup, Pelatihan Sertifikasi Hakim Lingkungan Hidup' (2014).

Pring GW and Canan P, SLAPPs: Getting Sued for Speaking Out (1st edn, Temple University Press 1996).

\section{Jurnal}

Gregorius JB, ‘Hak Asasi Manusia (HAM) Atas Lingkungan Hidup (Suatu Rekfleksi 
Nani Indrawati: Perlindungan Hukum Terhadap...

Sosio-Yuridis Atas Implementasi Penyelesaian Sengketa Lingkungan)' (2009) 39 Jurnal Hukum \& Pembangunan.

Merriam D and Benson J, 'Identifying and Beating a Strategic Lawsuit Against Public Participation' (1993) 3 Duke Environmental Law \& Policy Forum.

Nasution BJ, 'Kajian Filosofis Tentang Konsep Keadilan Dari Pemikiran Klasik Sampai Pemikiran Modern' (2014) 3 Yustisia Jurnal Hukum.

Sembiring R, 'Kriminalisasi Atas Partisipasi Masyarakat: Menyisir Kemungkinan Terjadinya SLAPP Terhadap Aktivis Lingkungan Hidup Sumatera Selatan' (2014) 1 Jurnal Hukum Lingkungan Indonesia.

\section{Laman}

Cornell Law School, 'US Constitution, First Amendment' <https://www.law. cornell.edu/constitution/first_amendment> accessed 27 May 2018.

Fauzi I, ‘Tiga Tahun Konflik Terus, The Rayja Ditawarkan 35 Miliar' Tribunnews <surabaya.tribunnews.com>.

Khalik A and Wulandari F, 'Buyat Bay Test Show High Mercury' < http:/ /www. minesandcommunities.org/article.php? $\mathrm{a}=1391>$.

United Nations, 'The Need to Ensure a Healthy Environment for The Well-Being Individuals' <www.un.org> accessed 27 May 2018.

United Nations Environment Programme, 'Declaration of The United Nations Conference on the Human Environment' <http:/ / www.unep.org> accessed 26 November 2014.

- - , 'Rio Declaration on Environment and Development' <http://www.unep. org> accessed 24 September 2014.

\section{Perundang-undangan}

Undang-Undang Dasar Negara Republik Indonesia 1945.

TAP No. XVII/MPR/1998 tanggal 13 November 1998 tentang Hak-Hak Asasi Manusia (HAM).

Burgerlijk Wetboek.

Undang-Undang Nomor 4 Tahun 1982 Tentang Ketentuan-Ketentuan Pokok 
Pengelolaan Lingkungan Hidup.

Undang-Undang Nomor 23 Tahun 1997 Tentang Pengelolaan Lingkungan Hidup.

Undang-Undang Nomor 39 Tahun 1999 Tentang Hak Asasi Manusia.

Undang-Undang Republik Indonesia Nomor 3 Tahun 2009 tentang Mahkamah Agung.

Undang-Undang Nomor 32 Tahun 2009 Tentang Pengelolaan dan Perlindungan Lingkungan Hidup.

Undang-Undang Republik Indonesia Nomor 48 Tahun 2009 tentang Kekuasaan Kehakiman.

Undang-Undang Republik Indonesia Nomor 11 Tahun 2020 tentang Cipta Kerja.

Keputusan Ketua Mahkamah Agung RI Nomor 36/KMA/SK/II/2013 tentang Pemberlakukan Pedoman Penanganan Perkara Lingkungan Hidup.

Republic of The Philippines Supreme Court, Rules of Procedures for evironmental Cases, Section 1 Rule 6

How to cite: Nani Indrawati, 'Perlindungan Hukum Terhadap Partisipasi Masyarakat (Anti SLAPP) Dalam Penegakan Hukum Lingkungan Hidup di Indonesia' (2022) Vol. 5 No. 1 Media Iuris. 
--Halaman ini sengaja dibiarkan kosong-- 